\title{
Knowledge Status of Cluster Bean (Cyamopsis tetragonoloba) Growers in Hyper Arid Zone of Rajasthan, India
}

\author{
P.S. Bagenia ${ }^{1^{*}}$ and Deepak Chaturvedi ${ }^{2}$ \\ ${ }^{1}$ Department Ext. Edu, College of Agriculture, Bharatpur SKNAU, Jobner, \\ Jaipur, Rajasthan, India \\ ${ }^{2}$ DEE, COA, SKRAU, Beechwal, Bikaner-334006, Rajasthan, India \\ *Corresponding author
}

\section{Keywords \\ Knowledge, Socio- economic status, \\ Extension contact, Agricultural \\ infrastructure, \\ Cropping intensity, \\ Crop rotation, \\ Cosmopoliteness \\ Article Info \\ Accepted: \\ 04 December 2017 \\ Available Online: \\ 10 January 2018}

A B S T R A C T

The study was carried out during the year 2010-11 in hyper arid partially irrigated western plain zone IC of Rajasthan with simple size of 316 respondents; they were cultivating clusterbean for last 5 year. To know the knowledge status of clusterbean growers and to find out the relationship between socio-economic and personal characteristics of the respondents with knowledge level about recommended production technologies of clusterbean Results highlighted that majority of the respondents were running their farm operations with poor infrastructure facilities however, less than 12.00 percent respondents had very high level of infrastructure facilities of the total respondents. The study revealed that majority of respondents had medium knowledge. Cultivators possessed technology wise high knowledge about irrigation and water conservation practices, sowing time, seed rate and method of sowing and used of improved seed. The farmers were possessed very little knowledge about application of culture, seed treatment and recommended spacing practices in respect to clusterbean technology, regarding technology wise knowledge. Among the personal and socio-economic characteristics of clusterbean growers majority of the respondents were moderate extension contacts, cosmopoliteness and small to medium level of land holding, educated upto primary to secondary standard whereas, more than half of the respondents were in middle aged group ranging from 36 to 55 years, partial irrigated farming conditions and material possession. While, 58.86 percent respondents fell in low degree of cropping intensity. Study further revealed that about two-third majority $(73.41 \%)$ of the respondents belonged to medium level of socioeconomic status. Whereas, majority of the respondents were running their farm operation with poor agricultural infrastructure facilities. Nine variables were included in the study, only one i.e., age of respondents was found negative and significant associated with their knowledge about recommended technology of clusdterbean cultivation. However, remaining eight variables namely education, landholding, socioeconomic status, extension contact, cosmopoliteness, material possession, cropping intensity and agricultural infrastructure facilities were found to be positive and significantly associated with their knowledge level about recommended production technology of clusterbean. 


\section{Introduction}

During world war-II, due to the nonavailability of locust bean gram, a search for alternative gum was started in USA at Wisconsin for paper industry and found guar gum as an ideal replacement. The by-product of guar industry, consists of outer seed coat and germ material, is called guar meal contains about 35-42 per cent protein. Of this, 95 per cent is digestible, making it an excellent protein supplement in amino acids. Enough gum remains in the meal to make it an excellent feed pelleting material. Toasting improves its palatability to livestock. India is a world leader for production of guar seed which is mainly grown in north-west states, Rajasthan, Gujarat, Haryana and Punjab. Clusterbean (Cymopsis tetragonoloba) grown well under wide range of soil conditions, guar fits well into crop rotation. It is a deep tap rooted legumes and is an excellent soil improving crop.

It works well in rotation with pearl millet a major staple cereals in its growing areas. Increased yield can be expected from crops following guar because of increased soil fertility. When harvested from seed, guar returns considerable dry organic matter to the soil surface. Rajasthan has largest area under cultivation of guar $(82.1 \%)$ followed by Haryana $(8.5 \%)$, Gujarat $(8.3 \%)$ and Punjab (1\%) which in turn producing 64, 22.12 and 2 per cent of guar seeds. The average productivity of the crop $\mathrm{kg}$ per hectare was 272 in Rajasthan, 881 in Haryana, 522 in Gujarat and 748 in Punjab respectively, whereas on all India basis it was $350 \mathrm{~kg}$ per hectare Whereas the potentiality of production is more than 15 quintal/hectare. This wide gap is actual and potential yield of guar may be attributed to low knowledge of scientific production technology. The per unit production of clusterbean mainly depends upon the technical know-how and extent of its use by the clusterbean growers. Therefore, it was thought opportune to probe into the level of knowledge of the clusterbean growers about the recommended clusterbean production technology.

This zone is characterized the most of the soil are sandy in texture and Aeolian in nature having high permeability as surface and very low in fertility with respect to almost all nutrients. Their nutrient and water retention capacity is very low. Considerable area has hard at varying depths. Some soils of this zone are gypsiferous, mean daily maximum temperature goes upto $42^{\circ} \mathrm{C}$ during summers and $24^{\circ} \mathrm{C}$ during winters.

Similarly, mean daily minimum temperature during summers comes down to $27^{\circ} \mathrm{C}$ and to freezing point during winters. The average rainfall varies from $141 \mathrm{~mm}$ in Jaisalmer to $325 \mathrm{~mm}$ in Churu. The area is characterized by strong south-west winds during summers with frequent dust storm. The major kharif crops of the zone are pearl millet, mothbean, clusterbean and cotton under irrigated condition under these situations farming is a challenging task. Keeping in this view the present study was conducted with following specific objectives:-

To study the socio-economic and personal characteristics of clusterbean growers.

To identify the availability of agricultural infrastructure among clusterbean growers.

To find out the knowledge status of the respondents about the recommended production technology of cluster bean.

To ascertain the relationship between personal and socio-economic characteristics of clusterbean growers with knowledge status of the respondents about clusterbean production technology. 


\section{Materials and Methods}

Rajasthan state comprises with ten agroclimatic zones and the Zone-1c (Hyper arid partial irrigated western plain zone) was selected purposely due to having maximum area and production of cluster bean for the study. As this zone is comprised of three district namely Bikaner, Churu and Jaisalmer. Out of these, Bikaner and Churu districts were selected randomly. Fifty per cent panchayat samities were selected randomly from the selected districts and four panchayat samities were selected from eight panchayat samities). Ten per cent gram panchayats were selected from selected panachayat samities and hence, 19 gram panchayats were also selected randomly. One village was randomly selected from each gram panchayat. A list of all the farmers who were growing cluster bean crop for last 5 years was so prepared from each selected village. From this list 40 per cent respondents were selected from the total cultivators of the selected villages on the basis of random sampling method. Thus, total sample of 316 respondents were selected for the study purpose. The respondents having both farming condition i.e., irrigated as well as rainfed. The knowledge for the present study refers to the amount of information and understanding of the respondents about improved farming practices. Knowledge status of the cultivators about recommended production technologies of clusterbean cultivation was measured. The knowledge score was calculated as sum of the total score obtained on correct response and converted into percentage. For the study purpose, 13 recommended production technologies of clusterbean were selected i.e., field preparation and soil, testing, use of improved seed, seed rate and methods of sowing, sowing time, spacing, seed treatment, application of culture, nutrient management, weeds irrigation and water conservation practices, plant protection measures and crop rotation. The data were collected by personal interview technique with the help of knowledge test specially prepared for this purpose during kharif 2010-11. The statistical tools like frequency, percentage, mean, standard deviation and correlation were used to analysed the date and interpreting accordingly. Based on mean and standard deviation the respondents were categorized in to three grouped according to their characteristics i.e., low, medium and high (Singh et al., 2012)

\section{Results and Discussion}

\section{Personal and Socio-economic characteristics of cluster bean growers}

The back ground information was ascertained according to their personal and socioeconomic characteristics from 316 selected respondents for present study.

Data presented in Table 1 revealed that 53.48 percent of total respondents were in the middle age group ranging from 36 to 55 years followed by farmers were in the old age group of above 55 years, while $18.67 \%$ respondents fell in the young age group upto 35 years, more than of the respondents $(53.80 \%)$ were educated primary to secondary standard, where as 14.55 percent farmers were illiterate, However, 22.15 percent respondent farmers can read and write only 9.50 percent farmers were educated upto graduation level. With regards to landholding, nearly 58.24percent farmers had small to medium size of land holding followed by 28.16 percent farmers were having big holding, only 13.60 percent farmers were having marginal size of landholding The data depicts from Table 1 that more than half of the respondents (51.59\%) had partially irrigated farming conditions. While, 31.01 and 17.40 percent respondents had rainfed and fully irrigated farming conditions respectively. About twothird majority $(73.41 \%)$ of clusterbean 
growers belonged to medium level of socioeconomic status, however 9.82 and 16.77 percent respondents were having low and high level of socio-economic status with regards to extension contact about 66.77 percent clusterbean growers were found in medium level where as 20.89 and 12.34 percent growers had high and low level of extension contact respectively. It is also clear from the table that majority of the respondents $(63.60 \%)$ belonged to medium level of cosmopoliteness. While, 20.28 (20.26) and 16.14 percent respondents had high and low level of cosmopoliteness respectively. More than half of the respondents $(57.28 \%)$ were found in medium level of material possession, whereas, 26.27 percent farmers were fell in low level of material possession only 16.46 percent clusterbean growers were having high level of material possession.

Similar in case of cropping intensity more than half of respondents i.e., (58.86\%) had low degree of cropping intensity. This might be fact that due to the sowing of kharif crop mainly depends on the monsoon. Whereas, 29.44 percent of the respondents were in medium degree of cropping intensity only few $(11.70 \%)$ respondents were having high degree of cropping intensity

Similar findings were also reported by Jadav (2005), Vaidya and Koshti (2005), Khule et al., (2009) and Singh et al., (2012)

\section{Availability of agricultural infrastructure facility among the respondents}

The Table 2 clearly indicates that the availability of irrigation among small farmers were 31.96 percent average, $31.01 \%$ satisfactory, 30.01 unsatisfactory and 6.96 percent very high. On the part of credit institutions it is noticed that 27.21 percent respondents have average facility, 31.65 percent (satisfactory), 31.02 percent (unsatisfactory) and only 10.12 percent very high. Regarding electricity power 54.75 percent respondents were having unsatisfactory facilities, $17.73 \%$ (average), $15.50 \%$ (satisfactory) and 12.02 percent very high respectively. In case of input supply agencies, it revealed that 40.82 percent respondents were having average facility 31.65 percent (unsatisfactory) and 21.52 percent satisfactory while few (6.01 percent) respondents were having average facility regarding transportation facilities 34.18, 27.54 and 23.10 percent respondents were in average, satisfactory and unsatisfactory level of transportation respectively and only 15.18 percent respondents had very high level of transportation facility. Table 2 also indicates that in case of communication media 37.35 percent of respondents were average facility, 23.42 percent were unsatisfactory, 22.46 percent were having satisfactory level of facility. Those who had very high facility constitutes only 16.77 percent. In case of technical assistance table also reveals that 37.66 percent respondents were having unsatisfactory level of facility, 35.13 percent have average, 18.03 percent have satisfactory and only 9.18 percent respondents here having very high level facility on their farming conditions.

Regarding marketing facilities, 40.18 percent respondents were having average facilities followed by satisfactory $(24.36 \%)$ and unsatisfactory level (19.63\%). Whereas, 15.83 percent of respondents were having very high level of marketing facilities in respect to clusterbean production technology concerned. Table further indicated that 37.03 percent respondents had unsatisfactory regarding farm buildings/storage. Followed 28.16 and 20.88 percent respondents were having under average and satisfactory level of farm building and storage facilities respectively. Only 13.93 percent respondents were having very high farm building storage facilities on their farm. 
Thus from the foregoing explanation, it may be concluded that majority of the respondents were running their farm operations with poor infrastructure facilities and those who are well and rich with infrastructure facilities were very few or less than $12.0 \%$ respondents of the total respondents examine under this study. The same results are supported by Singh (1991).

\section{Knowledge status of the cluster bean growers about their recommended production technologies}

The respondents were categorized into three categories with the help of mean and standard deviation. The collected data on farmer's knowledge regarding recommended production technologies of cluster bean cultivation are presented in Table 3.

The data evident in Table 3 reveals that 63.92 per cent respondents possessed medium level of knowledge regarding recommended production technology of cluster bean. Besides that 16.45 per cent and 19.63 per cent respondents possessed low and high level of knowledge respectively. It may be concluded that majority of the respondents had medium knowledge level regarding recommended production technology of cluster bean cultivation. This might be because of continued cultivation experience and exposure to mass media. The findings of the study are in line with the findings of Singh et al., (2001) Shinde (2002), Geengar (2006) and Goyal and Sharma (2007), Singh et al., (2012)

Technology-wise knowledge level of the respondents about recommended production technologies of clusterbean

There were altogether 13 technologies, identified for the analysis of knowledge level and the knowledge gap was also determined (Table 4).
Table 4 indicated that farmers' possessed highest knowledge about "Irrigation and water conservation practices" with 90.19 per cent and 9.81 per cent knowledge gap was observed. This was followed by "sowing time", "seed rate" and "method of sowing" and "use of improved seed, they were 86.08, $79.75,68.42$ per cent and 13.92, 20.25 and 31.58 per cent knowledge gap was observed, respectively. It is also evident from Table 2 that highest knowledge gap was observed in "application of culture" (84.49\%). This was followed by "seed treatment", "spacing" and "weed management", with 82.03, 68.04 and 61.71 per cent respondents, respectively. Whereas "harvesting and storage measures", plant protection measures" and "field preparation" and "soil testing" had knowledge level with $63.89,58.99$ and 58.47 per cent.

In case of crop rotation and nutrient management farmers had knowledge 52.95 and 52.29 per cent and knowledge gap 47.05 and 47.71 per cent was observed. Thus, from the above results, it can be concluded that in all the improved clusterbean technology, the knowledge gap existed from 9.81 to 84.49 per cent. As far as knowledge level regarding "weed management" and "spacing" in clusterbean cultivation was concerned only 38.29 and 31.96 per cent farmers accorded with rank tenth, eleventh. While only 17.97 per cent farmers were followed "seed treatment" and stood rank twelfth further only 15.51 per cent farmers have least knowledge about "application of culture" and awarded last rank.

From the above findings of Table 4 it could be concluded that majority of the farmers have substantial amount of knowledge about the irrigation and water conservation practices, recommended sowing time seed rate and method of sowing, while farmers had poor knowledge about application of culture, seed treatment, spacing and weed management. 
Table.1 Distribution of farmers according to their personal and socio-economic characteristics of clusterbean growers

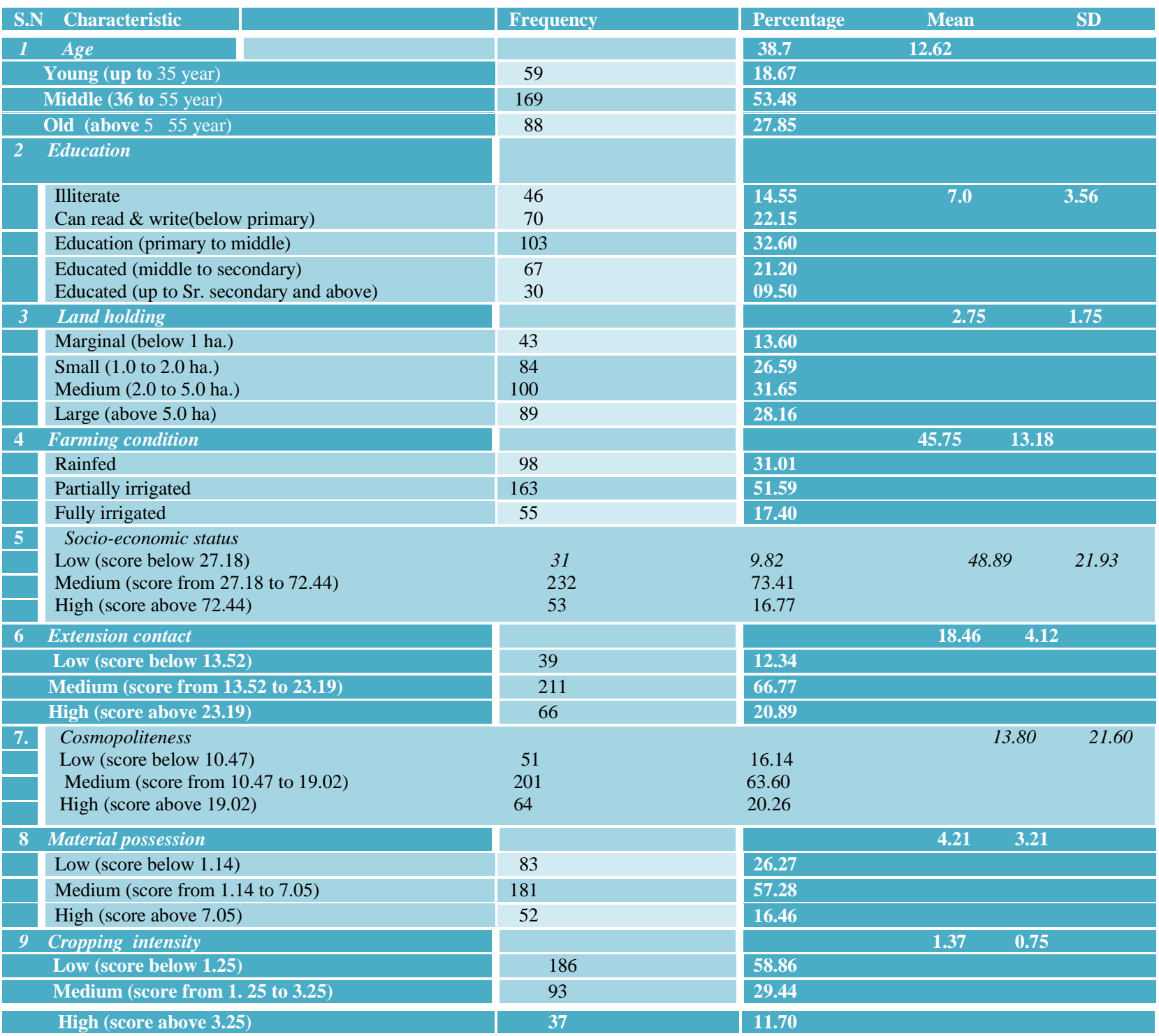

Table.2 Availability of infrastructure facilities among the clusterbean growers

\begin{tabular}{|c|c|c|c|c|c|c|c|c|c|}
\hline S.No. & Agrl. Infrastructure facilities & \multicolumn{8}{|c|}{ Availability of infrastructure facilities } \\
\hline & & \multicolumn{2}{|c|}{$\begin{array}{l}\text { Very high } \\
\text { Frequency \% }\end{array}$} & \multicolumn{2}{|c|}{$\begin{array}{l}\text { Satisfactory } \\
\text { Frequency \% }\end{array}$} & \multicolumn{2}{|c|}{$\begin{array}{l}\text { Average } \\
\text { Frequency } \%\end{array}$} & \multicolumn{2}{|c|}{$\begin{array}{l}\text { Facility at unsatisfactory } \\
\text { level Frequency } \%\end{array}$} \\
\hline 1. & Irrigation assets & 22 & 6.96 & 98 & 31.01 & 101 & 31.96 & 95 & 30.01 \\
\hline 2. & Credit institutions & 32 & 10.12 & 100 & 31.65 & 86 & 27.21 & 98 & 31.02 \\
\hline 3. & Electricity power & 38 & 12.02 & 49 & 15.50 & 56 & 17.73 & 173 & 54.75 \\
\hline 4. & Input supply Agencies & 19 & 6.01 & 68 & 21.52 & 129 & 40.82 & 100 & 31.65 \\
\hline 5. & Farm building/ storage & 44 & 13.93 & 66 & 20.88 & 89 & 28.16 & 117 & 37.03 \\
\hline 6. & Communication media & 53 & 16.77 & 71 & 22.46 & 118 & 37.35 & 74 & 23.42 \\
\hline 7. & Technical Assistance & 29 & 9.18 & 57 & 18.03 & 111 & 35.13 & 119 & 37.66 \\
\hline 8. & Marketing facilities & 50 & 15.83 & 77 & 24.36 & 127 & 40.18 & 62 & 19.63 \\
\hline 9. & Transportation & 48 & 15.18 & 87 & 27.54 & 108 & 34.18 & 73 & 23.10 \\
\hline
\end{tabular}


Table.3 Distribution of farmers according to their knowledge level about recommended Production technologies of cluster bean cultivation

\begin{tabular}{|l|}
\hline Knowledge level \\
\hline Low (score below 25.03) \\
\hline Medium (score from25.03 to 41.53) \\
\hline High (score above 41.53) \\
\hline Total \\
\hline
\end{tabular}

\begin{tabular}{|c|c|}
\hline Number of respondents & Percentage \\
\hline 52 & 16.45 \\
\hline 202 & 63.92 \\
\hline 62 & 19.63 \\
\hline 316 & 100.00 \\
\hline Mean 33.12 & SD 8.23 \\
\hline
\end{tabular}

Table.4 Knowledge level of the respondents about recommended production technologies of cluster bean cultivation

\begin{tabular}{|c|c|c|c|c|c|c|c|}
\hline $\begin{array}{l}\text { S. } \\
\text { No. }\end{array}$ & $\begin{array}{l}\text { Recommended } \\
\text { production technologies }\end{array}$ & $\begin{array}{l}\text { Maximum } \\
\text { Score }\end{array}$ & $\begin{array}{l}\text { Mean } \\
\text { score }\end{array}$ & $\begin{array}{c}\text { Knowledge } \\
\text { score } \\
\text { (percentage) }\end{array}$ & Rank & $\begin{array}{l}\text { Knowledge gap } \\
\text { (Percentage) }\end{array}$ & Rank \\
\hline 1. & $\begin{array}{l}\text { Field preparation \& soil } \\
\text { testing }\end{array}$ & 5 & 2.92 & 58.47 & VII & 41.53 & VII \\
\hline 2. & Use of improved seed & 5 & 3.42 & 68.42 & IV & 31.58 & $\mathbf{X}$ \\
\hline 3. & $\begin{array}{l}\text { Seed rate and method of } \\
\text { sowing }\end{array}$ & 3 & 2.39 & 79.75 & III & 20.25 & XI \\
\hline 4. & Sowing time & 3 & 2.58 & 86.08 & II & 13.92 & XII \\
\hline 5. & Spacing & 2 & 0.64 & 31.96 & XI & 68.04 & III \\
\hline 6. & Seed treatment & 4 & 0.70 & 17.97 & XII & 82.03 & II \\
\hline 7. & Application of culture & 4 & 0.62 & 15.51 & XIII & 84.49 & I \\
\hline 8. & Nutrient management & 8 & 4.18 & 52.29 & IX & 47.71 & V \\
\hline 9. & Weed management & 6 & 2.29 & 38.29 & $X$ & 61.71 & IV \\
\hline 10. & $\begin{array}{l}\text { Irrigation and water } \\
\text { conservation practices }\end{array}$ & 4 & 3.60 & 90.19 & I & 9.81 & XIII \\
\hline 11. & Plant protection measures & 5 & 2.94 & 58.99 & VI & 41.01 & VIII \\
\hline 12. & $\begin{array}{l}\text { Harvesting and storage } \\
\text { measures }\end{array}$ & 9 & 5.75 & 63.89 & V & 36.11 & IX \\
\hline 13. & Crop rotation & 3 & 1.58 & 52.95 & VIII & 47.05 & VI \\
\hline
\end{tabular}

Table.5 Relationship between socio-economic and personal characteristics of farmers and knowledge level about recommended production technology of clusterbean

\begin{tabular}{|l|l|l|}
\hline S.N & Independent variables & Knowledge (' $r$ ' correlation coefficient) \\
\hline 1. & Age & -0.140 \\
\hline 2. & Education & $0.2784^{* *}$ \\
\hline 3. & Land holding & $0.153^{* *}$ \\
\hline 4. & Socio-economic status & $0.341^{* *}$ \\
\hline 5. & Extension contact & $0.698^{* *}$ \\
\hline 6. & Cosmopoliteness & $0.786^{* *}$ \\
\hline 7. & Agriculture infrastructure & $0.859^{* *}$ \\
\hline 8. & Material possession & $0.531^{\text {** }}$ \\
\hline 9. & Cropping intensity & $0.564^{* *}$ \\
\hline
\end{tabular}

**Significant at 0.01 level of probability

It is further concluded that farmers had also good knowledge about use of improved seed, harvesting and storage measures, plant protection measures, field preparation and soil testing with regards to recommended production technology of clusterbean cultivation. Farmers had average knowledge about crop rotation and nutrient management 
in clusterbean cultivation. The poor knowledge about application of culture (Rhizobium/PSB), Seed treatment and spacing in clusterbean crop may be attributed to low interface level and little participation in extension programmes. Application of culture (Rhizobium and PSB), seed treatment, spacing and weed management as used of herbicide were not in the frame of reference of the farmers. These findings are in confirmation of Deshmukh et al., (1995), Sharma and Chauhan (2001), Shinde (2002), Geenger (2006), Goyal and Sharma (2007) and Sanchita et al., (2009) and Singh et al., (2012).

The data depicts from Table 5 shows that the negative significant association was found between age of farmers and their knowledge level. The extension contact, cosmopoliteness, material possession, agricultural infrastructure and cropping intensity of the farmers was highly significant with knowledge level of the clusterbean growers. The significant relationship was also observed between education, land holding and socio-economic status of the farmers with their knowledge level about recommended production technology of clusterbean. As far as related to findings Shinde (2002), Sharma (2008) and Singh et al., (2012) are reported more or less similar findings in their investigation.

It can be concluded that the majority of the respondents were having medium level of socio-economic status extension contact and cosmopoliteness. More than half of the respondents were medium material possession, partial irrigation condition, agricultural infrastructure facilities and age of growers ranging from 36 to 55 years, literate upto primary to secondary schooling, small to medium level of landholding. About three fifth of majority of the respondents were low degree of cropping intensity. Majority of the respondents were running their farm operations with poor infrastructure facilities. Study further concluded that the majority of the cultivators had medium knowledge level about recommended production technology of cluster bean cultivation. It was also found that cultivators possessed technology wise high knowledge regarding irrigation and water conservation practices, sowing time, recommended seed rate and method of sowing. Whereas, they possessed less knowledge about application of (PSB + Rhizobium) culture, seed treatment and spacing. Out of nine selected independent variables only one variable i.e., age was negative significantly associated with the knowledge level of the respondents about recommended production technology of clusterbean.

\section{References}

Choudhary, M., 1999. A study on knowledge and adoption of improved cultivation practices of mothbean in Bikaner district of Rajasthan. M.Sc. (Ag.) Thesis Rajasthan Agricultural University, Bikaner, Campus- Jobner.

Deshmukh, S.K., Shinde PS, Bhople RS 1995. Knowledge Status of Summer Groundnut grower in Vidarbha. Maha. J. of Extn. Edu., 14: 190-193.

Geenger, H.K. 2006. "knowledge and adoption of maize production technology by the tribal and non-tribal farmers in Jahazpur panchayat samiti of Bhilwara district (Raj.)”. M.Sc. (Ag.) Thesis Rajasthan Agricultural University, Campus-Jobner.

Goyal, M.C and Sharma, V.P. 2007. Knowledge of chickpea growers about biological practices of integrated pest management. Raj.J. of Extn. Edu., 15: $139-143$

Jadav, N.B. 2005. "Managerial ability of mango growers about scientific cultivation of mango orchards". 
Unpublished Ph.D. Thesis, GAU, Junagarh.

Khule, R.P., D.M. Lanjewar and V.D. Jagdale. 2009. Knowledge level of poddy growers about low cost cultivation technology. Asian J. of Ext.Edu. XXVII (1\&2); 25-28.

Sanchita Roy, Prasad, Angad and Daya Ram 2009. Level of knowledge of potato growing tribal farm women in Meghalaya. Ind.J.Extn.Edu. 45(1 and 2): 94-97.

Sharma, L.L. 2008. Knowledge adoption of improved soyabean cultivation technology among the farmers of Udaipur district of Rajasthan. M.sc. thesis submitted to MPUAT, Udaipur, and Rajasthan.

Sharma, L.L., Sharma, F.L. and Upadhayay, Y.B. 2008. Knowledge of soyabean growers in Udaipur districts of Rajasthan. Raj.J.Ext.Edu., 16: 124-128.

Sharma, V.P. and Chauhan, M.S. 2001. Increase in mustard yield through improved knowledge of plant protection technology, Rajasthan J. Ext. Edu., 8 \& 9: p 105-107.

Shinde, S.B. 2002."Knowledge of the farmers about improved cultivation practices of groundnut in Satara district. Maha. J. Extn. Edu, 21(1): 90-91.

Singh K, Singh P, 2001. Farmers' knowledge wheat production technology in eastern Rajasthan. Raj. J. Ext. Edu., 8 \& 9 (7174).

Singh, P., Jat, H.L. and Sharma, S.K. 2012. Farmer's technical experience about production technologies of mothbean cultivation in western region of Rajasthan. Indian Res.J.Ext.Edu. 12(1); 97-103.

Singh. K., 1991. Adoption and communication Behavior of Small Farmers in Bharatpur Dist. of Rajasthan Ph.D thesis (unpublished) Agra University, Agra (UP).

Souvenir 2008. Souvenir June 28-30' Indian Agricultural legume society, CAZRI, Jodhpur-Rajasthan.

Vaidya, V.R., Koshti, M.R. 2005. Knowledge and adoption of low cost crop cultivation and soil conservation technologies in cotton based cropping system, RRC report Dept. Ext. Edu. Dr. P.D.K.V. Akola pp. 18-37.

\section{How to cite this article:}

Bagenia, P.S. and Deepak Chaturvedi. 2018. Knowledge Status of Cluster Bean (Cyamopsis tetragonoloba) Growers in Hyper Arid Zone of Rajasthan, India. Int.J.Curr.Microbiol.App.Sci. 7(01): 264-272. doi: https://doi.org/10.20546/ijcmas.2018.701.029 